\title{
$\alpha$-MSH overexpression in the nucleus tractus solitarius decreases fat mass and elevates heart rate
}

\author{
K Eerola ${ }^{1,2,3}$, P Rinne', A M Penttinen ${ }^{1}$, L Vähätalo ${ }^{1,3}$, M Savontaus ${ }^{2,4}$ and E Savontaus ${ }^{1,5}$ \\ ${ }^{1}$ Department of Pharmacology, Drug Development and Therapeutics and Turku Center for Disease Modeling, \\ University of Turku, Kiinamyllynkatu 10, 20520 Turku, Finland \\ ${ }^{2}$ Turku Centre for Biotechnology, University of Turku, Turku, Finland \\ ${ }^{3}$ Drug Research Doctoral Program, University of Turku, Turku, Finland \\ ${ }^{4}$ Heart Center, Turku University Hospital and University of Turku, Turku, Finland \\ ${ }^{5}$ Unit of Clinical Pharmacology, Turku University Hospital, Turku, Finland
}

\author{
Correspondence \\ should be addressed \\ to E Savontaus \\ Email \\ eriika.savontaus@utu.fi
}

\begin{abstract}
The POMC pathway is involved in the regulation of energy and cardiovascular homeostasis in the hypothalamus and the brain stem. Although the acute effects of POMC-derived peptides in different brain locations have been elucidated, the chronic site-specific effects of distinct peptides remain to be studied. To this end, we used a lentiviral gene delivery vector to study the long-term effects of $\alpha$-MSH in the nucleus tractus solitarius (NTS) of the brain stem. The $\alpha$-MSH vector (LVi- $\alpha$-MSH-EGFP) based on the $\mathrm{N}$-terminal POMC sequence and a control vector (LVi-EGFP) were delivered into the NTS of C57BL/6N male mice fed on a western diet. Effects on body weight and composition, feeding, glucose metabolism, and hemodynamics by telemetric analyses were studied during the 12-week follow-up. The LVi- $\alpha-\mathrm{MSH}-$ EGFP-treated mice had a significantly smaller gain in the fat mass compared with LVi-EGFP-injected mice. There was a small initial decrease in food intake and no differences in the physical activity. Glucose metabolism was not changed compared with the control. LVi- $\alpha$-MSH-EGFP increased the heart rate (HR), which was attenuated by adrenergic blockade suggesting an increased sympathetic activity. Reduced response to muscarinic blockade suggested a decreased parasympathetic activity. Fitting with sympathetic activation, $\mathrm{LVi}-\alpha-\mathrm{MSH}-\mathrm{EGFP}$ treatment reduced urine secretion. Thus, the results demonstrate that long-term $\alpha$-MSH overexpression in the NTS attenuates diet-induced obesity. Modulation of autonomic nervous system tone increased the HR and most probably contributed to an anti-obesity effect. The results underline the key role of NTS in the $\alpha$-MSH-induced long-term effects on adiposity and in regulation of sympathetic and parasympathetic activities.
\end{abstract}

\section{Key Words}

> obesity

- blood pressure

- heart rate

brain stem

- $\alpha-\mathrm{MSH}$

- POMC

- lentivirus vector

- autonomic nervous system

- sympathetic

- parasympathetic

\section{Introduction}

The central melanocortin neuropeptide system consists of pro-opiomelanocortin (POMC)-derived melanocytestimulating hormones $(\alpha-, \beta-$, and $\gamma-\mathrm{MSH})$ and their endogenous antagonist agouti-related peptide (AGRP) that mediate their effects through $G$ protein-coupled melanocortin receptors 3 and 4 (MC3R and MC4R) (Lu et al. 1994, Fan et al. 1997). POMC is cleaved by protein convertase 1 (PC1) and 2 (PC2) to form MSH peptides and 
the other POMC-derived peptides such as $\beta$-endorphin and lipotropins ( $\beta$ - and $\gamma$-LPH) (Seidah et al. 1992). The melanocortin system plays a crucial role in the physiological regulation of energy balance (Biebermann et al. 2012). In the short term, central administration of MSH analogs decreases feeding and improves glucose metabolism (McMinn et al. 2000, Obici et al. 2001, Petervari et al. 2011). In the long term, melanocortin activation leads to reduced body weight and improved glucose tolerance in obese animal models (Savontaus et al. 2004, Lee et al. 2008, Wallingford et al. 2009, Diano 2011, Jeong et al. 2012a,b). On the other hand, the disruption of the melanocortin pathways leads to obesity in genetically modified mice and in humans. Mutations in the MC4R gene contribute to obesity underlining the importance of MSH peptides in the regulation of energy homeostasis in humans (Farooqi et al. 2000, Vaisse et al. 2000, Hinney et al. 2006).

POMC neurons in the arcuate nucleus (ARC) of the hypothalamus are known to be important recipients of circulating nutritional signals. However, many brain regions are interconnected to regulate energy homeostasis. POMC neurons in the ARC affect feeding behavior and energy metabolism, in addition to local hypothalamic projections, via neuronal projections to the nucleus tractus solitarius (NTS) in the brain stem (Cowley et al. 1999, Elmquist et al. 1999). Additionally, the NTS harbors a local POMC neuron population that accounts for $\sim 30 \%$ of the $\alpha$-MSH input to MCR-bearing neurons in the brain stem (Berthoud \& Morrison 2008). The NTS receives adiposity signals via local leptin receptors and satiety signals through vagal afferent neurons, and the POMC neurons have been suggested to modulate the strength of the vagal afferent response and enhance the anorexigenic response to satiety signals such as cholecystokinin (CCK) (Sutton et al. 2005). In line with this, melanocortin receptor activation in the NTS has been shown to acutely reduce meal size and food intake (Grill et al. 1998, Zheng et al. 2005, Berthoud \& Morrison 2008). In addition, thermogenesis is increased, which together with anorexia could contribute to lower body weight gain in the long term (Skibicka \& Grill 2009). Apart from the metabolic implications, the NTS is involved in the regulation of cardiovascular function (Zanutto et al. 2010) and melanocortins are known to exert direct cardiovascular effects in this brain region. While acute administration of $\alpha$-MSH into the cerebroventricular system produces hypertensive effects, most studies report that $\alpha$-MSH administration into the NTS decreases blood pressure and heart rate (HR) through a reduced sympathetic nervous system (SNS) activity (Li et al. 1996, Pavia et al. 2003, Tai et al. 2007).
Although the roles of different brain regions in mediating the short-term effects of melanocortins have been widely studied, the long-term site-specific effects have drawn less attention. Viral gene delivery was used to overexpress POMC in the ARC or in the NTS and the results showed anti-obesity effects that in the ARC varied with the animal models used, but in the NTS were persistent (Li et al. 2003, 2005, 2007, Zhang et al. 2010). Although the effects match the acute effects of $\alpha$-MSH, it is possible that the other POMC-derived peptides contribute to the long-term effects. The melanocortin peptides alone have different affinities for the melanocortin receptors and show different metabolic effects. In addition, $\gamma$-LPH has been shown to decrease food intake, $\beta$-LPH to induce lipolysis, and $\beta$-endorphin to regulate feeding behavior and blood pressure (Richter et al. 1990, Eichhorn et al. 1995, Appleyard et al. 2003, Low et al. 2003, Tung et al. 2006).

In order to elucidate the chronic site-specific effects of distinct POMC-derived peptides, we created a lentiviral vector overexpressing only $\alpha$-MSH (POMC). In our previous work, we delivered it to the ARC of the hypothalamus of $\mathrm{C} 57 \mathrm{Bl} / 6 \mathrm{~N}$ male mice and showed that chronic stimulation of the melanocortin system using $\alpha$-MSH only in the ARC led to a food intake-independent attenuation of high-fat diet-induced obesity in the long term (Eerola et al. 2013). In the current work, we used the $\alpha$-MSH lentiviral delivery system and targeted the NTS. The aim was to test the hypothesis that the acute effects of $\alpha$-MSH administration into the NTS reported earlier are sustained and lead to long-term changes in body composition and hemodynamics in mice fed on a western-type diet when $\alpha-\mathrm{MSH}$ is overexpressed in the NTS.

\section{Materials and methods}

\section{Animals}

Two-month-old C57BL/6N male mice obtained from Harlan Laboratories B.V. (Venray, The Netherlands) were used in the experiment. Animal care was in accordance with the guidelines of the International Council of Laboratory Animal Science (ICLAS), and the national animal care and use committee approved all experimental procedures. Mice were kept single housed in an animal room maintained at $21 \pm 1{ }^{\circ} \mathrm{C}$ with a fixed $12 \mathrm{~h}$ light: $12 \mathrm{~h}$ darkness cycle. They were fed on a western-type diet containing $25 \mathrm{kcal} \%$ from fat (anhydrous milk fat), $58 \mathrm{kcal} \%$ from carbohydrate (50 kcal\% of which is from sucrose), $17 \mathrm{kcal} \%$ from protein, and $0.17 \mathrm{~g} \%$ cholesterol (RD Lower Fat Western Diet With 25\% Fat, D05022804,

Published by Bioscientifica Ltd 
Research Diets, New Brunswick, NJ, USA). Food and water were available ad libitum. After 2 weeks on the diet, mice were divided into two treatment groups matched for body weights. A complete timetable of the study can be viewed in Fig. 1A.

\section{Lentiviral vector}

Second-generation lentiviral vector $\mathrm{LVi}-\alpha$-MSH-EGFP and control vector LVi-EGFP were produced according to standard protocols as described previously (Eerola et al. 2013). In short, human embryonic kidney cells (HEK293T) grown in DMEM supplemented with 10\% fetal bovine serum, $2 \mathrm{mM}$ L-glutamine $(1.5 \mathrm{~g} / \mathrm{l}$ sodium bicarbonate and $4.5 \mathrm{~g} / \mathrm{l}$ glucose $)$, penicillin $(100 \mathrm{U} / \mathrm{ml})$, and streptomycin $(100 \mu \mathrm{g} / \mathrm{ml})$ (Sigma-Aldrich Co.) were cotransfected with the vector plasmid (pWPI- $\alpha$-MSH-EGFP or pWPI-EGFP) and two helper plasmids: pCMV-pR8.91 (a packaging plasmid) and pMD2G (an envelope plasmid). Viral particles were harvested from filtered cell growth medium by ultracentrifugation and resuspended in sterile PBS solution (Sigma-Aldrich Co.). Titers (transducing units/ml $(\mathrm{TU} / \mathrm{ml})$ ) were determined by fluorescence-based flow cytometry. The $\alpha$-Msh gene construct is based on the endogenous N-terminal POMC sequence allowing for proper intracellular processing to produce biologically active and secreted $\alpha$-MSH. The bicistronic construct allows for production of the enhanced green fluorescent protein $(E g f p)$ reporter gene simultaneously. The lentiviral vector uses the glycolipid envelope of the vesicular stomatitis virus (VSVG) in combination with the ubiquitous human elongation factor alpha (hEF1 $\alpha$ ) promoter that has been shown to almost exclusively target neurons (Jakobsson et al. 2003).

\section{Stereotaxis}

Ketamine (75 mg/kg) (Pfizer, Inc., New York, NY, USA) analgesia was administered intraperitoneally $20 \mathrm{~min}$ before the injections and the animals were anesthetized using isoflurane. Then, $2.1 \times 10^{5}$ TU of LVi-EGFP or LVi$\alpha$-MSH-EGFP in similar volumes were delivered bilaterally into the NTS by stereotaxis using coordinates: anteriorposterior (AP) $-3.50 \mathrm{~mm}$ from the interaural structure, dorsal-ventral (DV) $-4.50 \mathrm{~mm}$ and medial-lateral (ML) $\pm 0.50 \mathrm{~mm}$. A Stoelting stereotaxic frame and a Stoelting QSI injector (Stoelting Co., Wood Dale, IL, USA) were used to deliver a total volume of $1 \mu \mathrm{l}$ of the viral suspension at $0.1 \mu \mathrm{l} / \mathrm{min}$. The needle was withdrawn slowly $10 \mathrm{~min}$ after injection relieving pressure created by the viral suspension.

At the end of the experiment, the coronal brain sections of both LVi- $\alpha$-MSH-EGFP- and LVi-EGFPinjected animals were analyzed for EGFP expression to define the site of injection. Mice with injections that hit the fourth ventricle or that were located outside the NTS region of interaural AP -3.20 to $-3.80 \mathrm{~mm}$ (Franklin \& Paxinos 1997) were excluded from the final results $(n=5$ in the LVi- $\alpha$-MSH-EGFP and $n=3$ in the LVi-EGFP group). Overall, ten mice in the LVi-EGFP group and nine in the LVi- $\alpha$-MSH-EGFP group were included in the final results.

\section{Body weight and food consumption}

Body and food weights were measured twice a week until day 53. Food spillage was accounted for in all measurements by carefully checking the bedding (Tapvei aspen) for fallen blue-colored food crumbs and including the crumbs in the remaining food.

\section{Body composition}

Body composition (fat tissue and lean tissue in grams) was assessed on the day of the treatment, and at 21 and 56 days after the treatment using an EchoMRI-700 quantitative nuclear magnetic resonance whole-body composition analyzer (Echo Medical Systems, Houston, TX, USA).

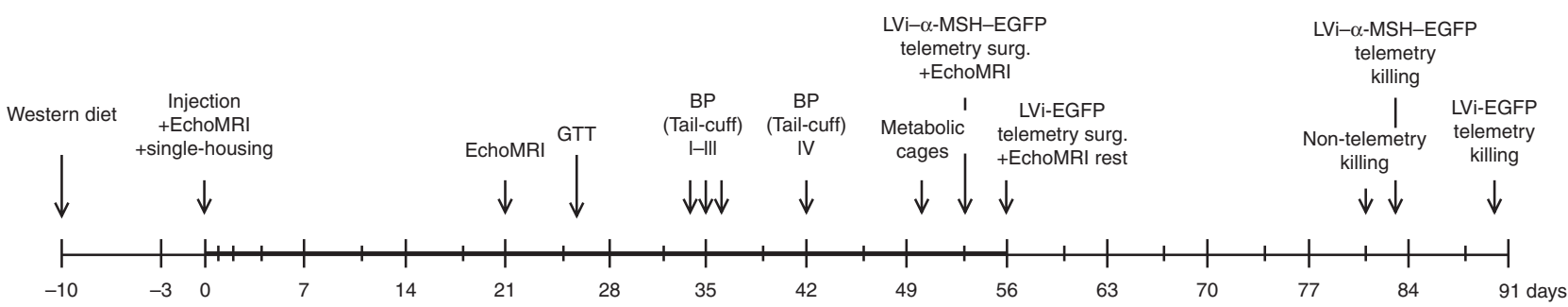

Figure 1

Experimental timetable. EchoMRI, body composition analysis; GTT, glucose tolerance test; BP, blood pressure.

http://joe.endocrinology-journals.org DOI: $10.1530 / \mathrm{JOE}-14-0064$
C 2014 Society for Endocrinology Printed in Great Britain
Published by Bioscientifica Ltd. 
Mice that were awake were placed in the holder for the period of 1-3 min for the analysis.

\section{Estimation of energy expenditure}

Total energy expenditure $\left(\mathrm{TEE}_{\mathrm{bal}}\right)$ was calculated based on the energy balance technique that was previously validated and shown to highly correlate with $\mathrm{TEE}_{\text {bal }}$ measured by indirect calorimetry (Ravussin et al. 2013). The equation used is

$$
\begin{aligned}
\mathrm{TEE}_{\text {bal }}= & \mathrm{EI}-(\Delta \text { somatic fat energy } \\
& +\Delta \text { somatic fat-free energy })
\end{aligned}
$$

where EI is the total energy intake (kcal), $\Delta$ somatic fat energy is the change in fat mass $(\mathrm{g}) \times 9.0 \mathrm{kcal} / \mathrm{g}$ for negative change or $12.3 \mathrm{kcal} / \mathrm{g}$ for positive change, and $\Delta$ somatic fat-free energy is the change in lean mass $(\mathrm{g}) \times 1.0 \mathrm{kcal} / \mathrm{g}$ for negative change or $2.2 \mathrm{kcal} / \mathrm{g}$ for positive change. $\mathrm{TEE}_{\text {bal }}$ was calculated for the period after day 21 to exclude the recovery from the injections. To get mean daily $\mathrm{TEE}_{\mathrm{bal}}$ ( $\mathrm{kcal} / 24 \mathrm{~h}$ ), the result was divided by the number of days.

\section{Intraperitoneal glucose tolerance test}

At 26 days after the injections, mice were first fasted for $4 \mathrm{~h}$ and then administered intraperitoneally with glucose ( $5 \%$ (wt/vol), $1 \mathrm{~g} / \mathrm{kg}$ body weight). Tail vein blood samples ( $5 \mu \mathrm{l})$ were withdrawn by incision at $0,20,40,60$, and 90 min from mice restrained shortly. Blood glucose concentration was measured using the Precision Xtra Glucose Monitoring Device (Abbott Diabetes Care).

\section{Metabolic cage}

At 50 days after injections, mice were weighed and placed into wire bottom metabolic cages (Harlan Laboratories, Inc., Indianapolis, IN, USA) over a period of $24 \mathrm{~h}$ during which water and food consumptions, and fecal and urine excretions were measured.

\section{Blood pressure by tail-cuff}

Systolic blood pressure (sBP) and HR were measured optically in conscious, restrained mice using the tail-cuff system (TSE System International Group, Bad Homburg, Germany). Mice were acclimated to the apparatus on 2 consecutive days (days 34-35) before the measurements on days 36 and 42 after treatments. The mean of 6-10 measurements from each mouse was recorded.

\section{Blood pressure telemetry and pharmacological testing}

$\mathrm{BP}$ and HR were measured in conscious, unrestrained mice using a radiotelemetry system (TA11PA-C10 and Dataquest software, Data Sciences International, St Paul, MN, USA) as described previously (Rinne et al. 2008, 2013). The operation for placing the telemetric devices were carried out between days 56 and 60 in four mice in each group. Baseline values for hemodynamic parameters were recorded after a recovery period of 7 days for 3 consecutive days and the results are given as $12 \mathrm{~h}$ means over nonactive light and active darkness periods. Subsequently, autonomic control of BP and HR was assessed using pharmacological muscarinic blockade by atropine $(2 \mathrm{mg} / \mathrm{kg}), \quad \beta_{1}$-adrenergic blockade by metoprolol ( $4 \mathrm{mg} / \mathrm{kg})$, and $\alpha_{1}$-adrenergic blockade with prazosin $(1 \mathrm{mg} / \mathrm{kg})$ comparing with saline $(10 \mathrm{ml} / \mathrm{kg})$ as described earlier (Rinne et al. 2013).

\section{Tissue collection and preparation}

Mice were killed 70 days after the injections, except for mice that underwent telemetric measurements, which were killed 82-89 days after the injections. Mice were killed at $0800 \mathrm{~h}$ after a 4 -h fast. Blood samples were collected by terminal intracardiac puncture under pentobarbital sodium $(70 \mathrm{mg} / \mathrm{kg})$ anesthesia. A total of $500 \mu \mathrm{l}$ blood per mice were collected in serum separation tubes (CAPIJECT T-MG, Terumo Medical Corporation, Elkton, MD, USA).

Whole brain samples were collected, rinsed with PBS solution ( $\mathrm{pH}$ 7.4), and frozen with isopentane in O.C.T solution (Sakura Finetek, Torrance, CA, USA). Brain sections were collected using a motorized Leica CM$3050 S$ cryostat in $10 \mu \mathrm{m}$ sections (Leica Microsystems $\mathrm{GmbH}$, Wetzlar, Germany) and stored isolated from air at $-80^{\circ} \mathrm{C}$. Fluorescent samples were post-fixed in $4 \%$ PFA-PBS solution, dried, and mounted with a fluorescent preserving hardening mounting medium with DAPI (Vector Laboratories, Inc., Burlingame, CA, USA) and examined using a Leica DM R microscope (Leica Microsystems $\mathrm{GmbH}$ ) under fluorescence filters and visual light. Fluorescent images were acquired using a Zeiss Axioimager M1 and ZEN 2012 software (Carl Zeiss Microscopy LLC, New York, NY, USA).

Mesenteric and retroperitoneal white adipose tissue (WAT) and interscapular brown adipose tissue (BAT) depots, liver, heart, and kidney were collected and weighed.

The data collected on the day of termination include all mice despite their different follow-up times. The data were analyzed for treatment and the time of termination effects

Published by Bioscientifica Ltd. 

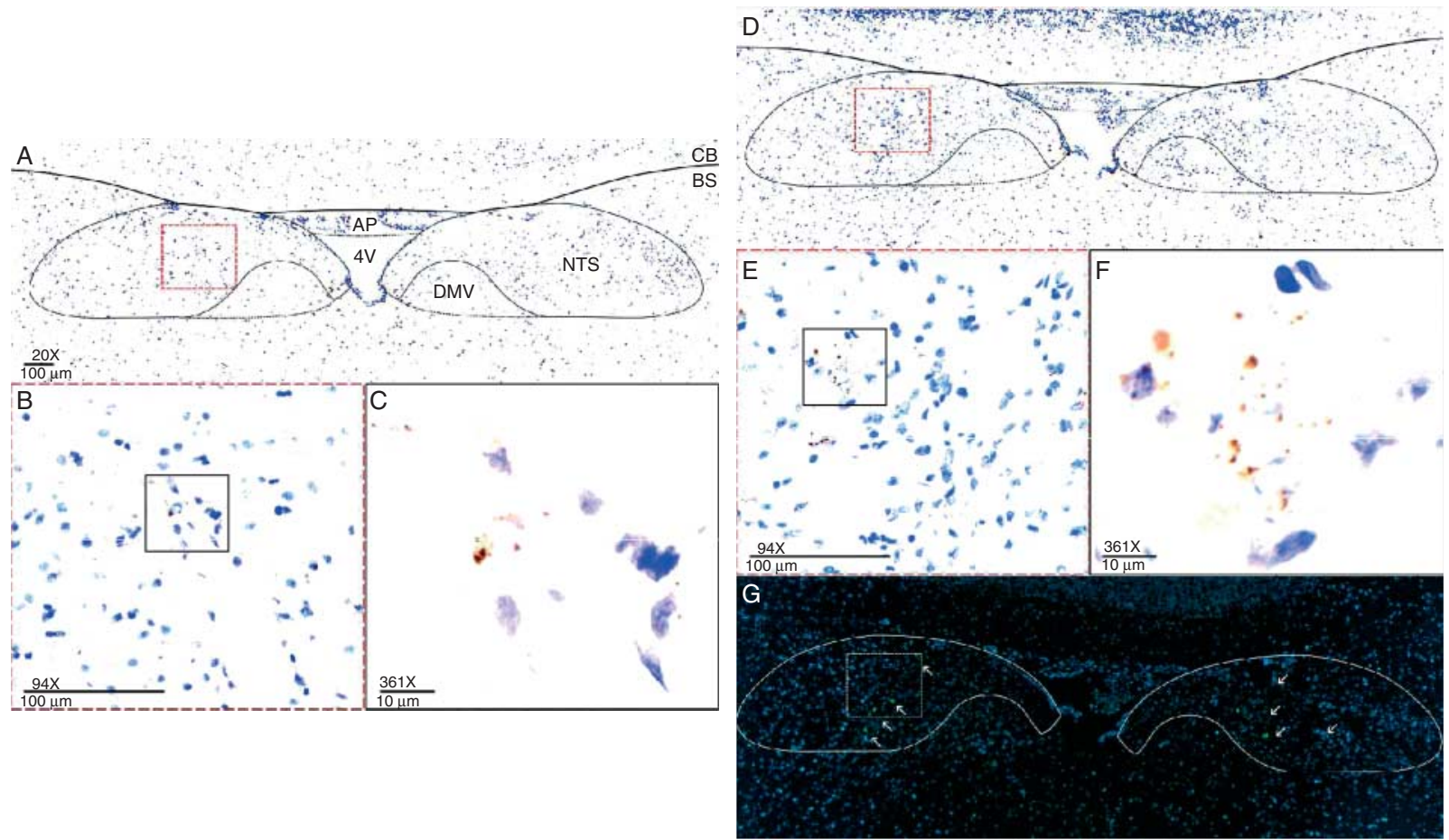

Figure 2

Representative images of $\alpha$-MSH immunoreactivity in the coronal sections of the brain stem in the interaural $-3.5 \mathrm{~mm}$ position of LVi-EGFP-injected mouse ( $A, B$ and $C$ ) and LVi- $\alpha$-MSH-EGFP-injected mouse (D, E, F and G). (A and D) Magnified (20X) image of the NTS (black outline) and infection site (red box). $(B$ and E) Magnified $(40 \times)$ image of the injection site. ( $C$ and F) Magnified $(63 \times)$ image of the black box in (B) and (E). Cresyl (blue color) indicates nuclei and $\mathrm{DAB}$ (brown color) the location of $\alpha$-MSH immunoreactivity. Scale bar and magnification factor located in the lower left corner of each image.

(G) Fluorescent image of an adjacent section to D, DAPI (blue fluorescent color) indicates nuclei and EGFP (green fluorescent color) transduction of cells by the lentiviral vector. White dotted box indicates the injection site and white arrows point to EGFP. AP, area postrema; BS, brain stem; CB, cerebellum; DMV, dorsal motor nucleus of the vagus; NTS, nucleus tractus solitarius; $4 \mathrm{~V}$, the fourth ventricle.

by two-way ANOVA and pooling the results was justified by a non-significant time effect and by a treatment effect that was similar to the analysis of the pooled data.

\section{$\alpha-M S H$ immunohistochemistry}

Immunohistochemistry was performed using the avidinbiotin-peroxidase method. Briefly, tissue slides were postfixed in 4\% paraformaldehyde-PBS solution for $5 \mathrm{~min}$. Endogenous peroxidase was inactivated by a $20 \mathrm{~min}$ quench in methanol containing $3 \% \mathrm{H}_{2} \mathrm{O}_{2}$. Fc receptors were blocked with $10 \%$ normal horse serum in PBST $0.1 \%$ solution. The $\alpha$-MSH antibody (Phoenix Pharmaceuticals, Inc., Burlingame, CA, USA, Cat. No.: H-043-01) was incubated at a concentration of $1 / 1000$ overnight at $4{ }^{\circ} \mathrm{C}$ in PBST $0.1 \%$ solution. Following this, the sections were incubated with a biotinylated horse anti-rabbit IgG antibody (1/300) (Vector Laboratories) for $1 \mathrm{~h}$ at room temperature in PBS solution. VectorElite ABC (Vector Laboratories) was used to amplify the signal and visualized using 3,3-diaminobenzidine (DAB). The tissue was then counterstained using cresyl violet in order to visualize cell nuclei. The specificity and characteristics of the $\alpha$-MSH antibody were previously verified (Miller et al. 2003). The specificity was also tested by adding $100 \mathrm{mM}$ synthetic $\alpha$-MSH (Tocris Bioscience, Bristol, UK Cat. No. 3013) in the primary antibody solution, whereby all immunoreactivities were abolished (Supplementary Figure 1, see section on supplementary data given at the end of this article).

Coronal brain stem sections covering the NTS in $100 \mu \mathrm{m}$ increments from interaural structure from -3.1 to $-3.9 \mathrm{~mm}$ were immunostained for $\alpha$-MSH and positive $\mathrm{DAB}$ staining was quantified using automated DAB calculations. Using a light microscope, $20 \times$ images of the sections were acquired using a BestScope BUC4500C camera (BestScope International Limited, Beijing, China) and IScapture 2.6 software (Fuzhou Xintu Photonics Co., Fuijan, China). The image series were merged together using the Windows Ice 1.3.3.0 software (Microsoft Co.). The NTS region was then cropped from the images according to Franklin and Paxinos as shown in Fig. 2 (Franklin \& Paxinos 1997). Following this, the

Published by Bioscientifica Ltd. 


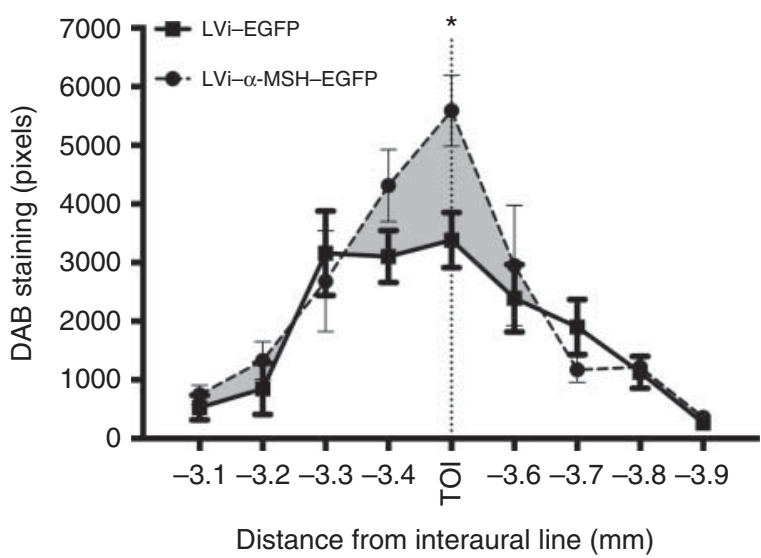

Figure 3

Semiquantification of $\alpha$-MSH immunoreactivity (DAB stained pixels) in the NTS -3.9 to $-3.1 \mathrm{~mm}$ from the interaural structure in LVi-EGFP-treated animals $(n=4)$ and LVi- $\alpha$-MSH-EGFP-treated animals $(n=6)$. TOI, target of infection. ${ }^{*} P<0.05$, Mann-Whitney $U$ test.

cropped images were analyzed using the ImageJ 1.47 software (Rasband 1997-2012), brown DAB staining was isolated, and the pixel count of specific DAB staining was calculated automatically using the color_deconvolution/H\&E DAB program (Ruifrok et al. 2003). Pixel counts were acquired from both hemispheres separately in four mice per group and from one hemisphere only in three additional mice in the LVi- $\alpha$-MSH-EGFP group. The results include 3-8 samples per rostrocaudal segment in each group. Areas under the curve (AUC) for the mean pixel count curves in Fig. 3 were calculated and used to estimate the relative $\alpha$-MSH levels in the whole NTS area.

\section{Serum insulin, non-esterified free fatty acids and cholesterol levels}

Serum insulin was measured using the Mercodia Ultrasensitive Mouse Insulin ELISA Kit (Mercodia AB, Uppsala, Sweden). The non-esterified free fatty acids (NEFAs) were determined using the NEFA-C Reagent set (Wako Chemicals GmbH, Neuss, Germany) and serum total cholesterol using the Cayman Cholesterol Assay Kit (Cayman Chemical Company, Ann Arbor, MI, USA).

\section{Urinary creatinine}

From mice placed in metabolic cages, 24-h urine samples were collected and stored at $-80{ }^{\circ} \mathrm{C}$ until use for a creatinine assay (Cayman Chemical Company) relying on the Jaffé reaction to measure creatinine concentration, which then was multiplied by $24-\mathrm{h}$ urine volume.

\section{Uncoupling protein 1 mRNA}

The mRNA levels of uncoupling protein 1 (Ucp1) in BAT were analyzed by quantitative real-time PCR (qPCR). Briefly, the mRNA was first extracted and converted into cDNA using a High-Capacity RNA-to-cDNA Kit (Applied Biosystems) according to the manufacturer's instructions on a GeneAmp PCR System 9600 (Perkin Elmer, Waltham, MA, USA). Target genes were quantified by 7300 Real-Time PCR System (Applied Biosystems) relative to the housekeeping gene ribosomal protein s29 (Rps29) using following primers (upstream and downstream respectively); 5'-ATG GGT CAC CAG CAG CTC TA-3' and 5'-AGC CTA TGT CCT TCG CGT ACT-3', using the SYBR-Green method (Kapa Biosystems, Woburn, MA, USA), and the following primers for $U c p 1$ (upstream and downstream respectively) 5'-ACT GCC ACA CCT CCA GTC ATT-3' and 5'-CTT TGC CTC ACT CAG GAT TGG-3'.

\section{Statistical analysis}

Weight gain, food intake, body composition, and telemetric measurements over time and glucose tolerance test were analyzed by two-way ANOVA. If the interaction was significant, the treatment effects were compared in different time points by Bonferroni post-hoc analysis. The parametric unpaired $t$-test was used for comparing normally distributed single parameters and the Mann-Whitney $U$ test for parameters with small numerical nomenclature between LVi- $\alpha$-MSH-EGFP and LVi-EGFP treatments. AUCs were calculated by the trapezoidal method. Statistical analyses were performed using GraphPad Prism 6.0 (La Jolla, CA, USA). Data are expressed as means \pm s.E.M. The results were considered statistically significant at $P<0.05$.

\section{Results}

\section{Transgene expression and $\alpha$-MSH immunostaining}

The exact sites of successful LVi- $\alpha$-MSH-EGFP injections were located close to the target as presented in Supplementary Figure $2 \mathrm{~A}$, see section on supplementary data given at the end of this article. Six injections were successful bilaterally and three unilaterally. In the five excluded mice, the injections flanked the NTS dorsally or posteriorly.

The $\alpha$-MSH immunoreactivity in the LVi-EGFP control group was mostly located in the close proximity of the fourth ventricle or the central canal in the commissural

Published by Bioscientifica Ltd. 
NTS with minor positive locations in the dorsal and medial NTS (Fig. 2A, B and C). By contrast, $\alpha$-MSH immunoreactivity in the LVi- $\alpha$-MSH-EGFP samples was evident as a more intense and widespread staining descending from dorsolateral and dorsomedial to medial NTS (Fig. 2D and E) and spreading on average over an area of $255 \pm 14 \mu \mathrm{m}$ in width $(n=5)$. The EGFP fluorescence in the same area supported that the $\alpha$-MSH was derived from the transgene (Fig. 2G). The quantification results indicate a significant $65 \%$ increase in $\alpha$-MSH immunoreactivity in the interaural structure of $-3.5 \mathrm{~mm}$ sections fitting with the coordinates used in the injections and the actual sites of successful injections (Fig. 3). The overall $\alpha$-MSH immunoreactivity in the NTS as estimated by comparing the AUC values of the mean pixel count curves (Fig. 3) was $31 \%$ more in the LVi- $\alpha$-MSH-EGFP mice (AUC: 1288 vs 983 pixels $\times$ section).

\section{Body weight and food intake}

There were no differences in mean body weights between treatments over time until day 53 (Fig. 4A). At the end of the experiment, LVi- $\alpha$-MSH-EGFP-treated mice weighed significantly less than the LVi-EGFP mice (Table 1). The operation needed for viral injections caused a decrease in body weights in both groups, and the initial weight was achieved in the LVi-EGFP group by day 21 and in the LVi$\alpha$-MSH-EGFP group by day 28 . Cumulative food intake was significantly lower in the LVi- $\alpha$-MSH-EGFP group compared with LVi-EGFP-treated mice during the catchup growth period $0-21$ days $(61.0 \pm 1.9$ vs $66.9 \pm 2.0 \mathrm{~g}$, $P<0.05$ ), but the difference disappeared by day 53 $(157.6 \pm 3.7$ vs $166.0 \pm 4.3 \mathrm{~g}, P=\mathrm{NS})$. When analyzed over time, feeding was significantly reduced in the LVi- $\alpha-\mathrm{MSH}-$ EGFP group on days 2-4 (Fig. 4B). However, when food intake was expressed as a change from baseline (average intake over days -10 to 0 ), there was no significant difference between the groups indicating that the reduced intake in the LVi- $\alpha$-MSH-EGFP group could be due to the initially lower intake in that group (Fig. 4C). Starting from day 21, food intake differed by being less fluctuating between biweekly measurements in the LVi- $\alpha$-MSH-EGFP group. The fluctuation might have been related to weekly routines in the animal facilities or the disturbed weight development after experimental procedures.

\section{Body composition}

LVi- $\alpha$-MSH-EGFP-treated animals showed a significantly lower absolute fat mass and a change in fat mass 56 days
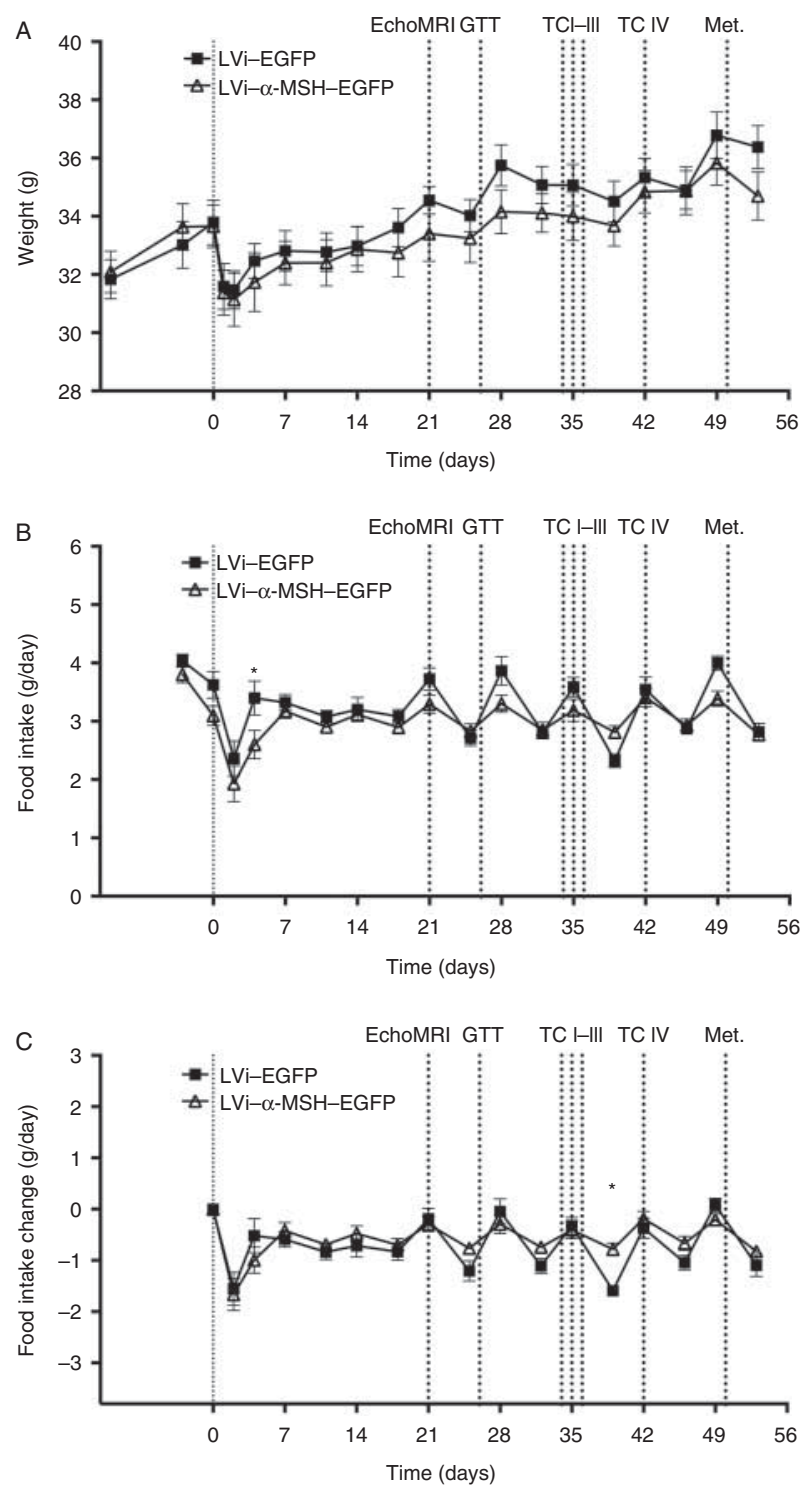

Figure 4

(A) Body weight, (B) food intake, and (C) change from baseline in food intake of mice injected into the nucleus tractus solitarius with lentiviral vectors $\mathrm{LVi}-\alpha-\mathrm{MSH}-\mathrm{EGFP}(n=9)$ or LVi-EGFP-LVi $(n=10)$, *P<0.05, two-wayANOVA followed by the Bonferroni post-test. Time points of body composition analysis (EchoMRI), glucose tolerance test (GTT), tail-cuff blood pressure training and measurements (TC), and urine and fecal collections in the metabolic cages (Met.) are indicated as dotted vertical lines.

after the injection (Fig. 5C and D). The gain in fat mass of LVi- $\alpha$-MSH-EGFP-treated mice tended to be smaller and weight change was significantly decreased also when comparing with mice with unsuccessful $\mathrm{LVi}-\alpha-\mathrm{MSH}-$ EGFP injections (Supplementary Figure 2D and E). There were no evident differences in weight or fat mass gain between mice that received unilaterally and bilaterally successful LVi- $\alpha$-MSH-EGFP injections.

Published by Bioscientifica Ltd. 
Table 1 Body and tissue weights at termination in LVi-EGFPtreated mice $(n=10)$ and LVi- $\alpha$-MSH-EGFP-treated mice $(n=8)$

\begin{tabular}{|c|c|c|}
\hline & LVi-EGFP & $\begin{array}{c}\text { LVi- } \alpha-M S H- \\
\text { EGFP }\end{array}$ \\
\hline BW (g) & $38.5 \pm 0.9$ & $35.3 \pm 0.9 *$ \\
\hline Liver (mg) & $2109+116$ & $2075 \pm 158$ \\
\hline Heart (mg) & $148 \pm 3$ & $149 \pm 7$ \\
\hline Kidney (mg) & $214 \pm 5$ & $208 \pm 9$ \\
\hline Mesenteric fat (mg) & $807 \pm 69$ & $552 \pm 38^{\dagger}$ \\
\hline Retroperitoneal fat (mg) & $335 \pm 18$ & $256 \pm 27 *$ \\
\hline Interscapular brown fat (mg) & $247 \pm 14$ & $188 \pm 17 *$ \\
\hline Liver/BW (\%) & $5.48 \pm 0.27$ & $5.84 \pm 0.33$ \\
\hline Heart/BW (\%) & $0.39 \pm 0.01$ & $0.42 \pm 0.02$ \\
\hline Kidney/BW (\%) & $0.56 \pm 0.03$ & $0.59 \pm 0.02$ \\
\hline Mesenteric fat/BW (\%) & $2.07 \pm 15$ & $1.55 \pm 0.07^{\dagger}$ \\
\hline Retroperitoneal fat/BW (\%) & $0.87 \pm 0.04$ & $0.71 \pm 0.06 *$ \\
\hline Interscapular brown fat/BW (\%) & $0.64 \pm 0.03$ & $0.53 \pm 0.05 *$ \\
\hline
\end{tabular}

BW, body weight $* P<0.05,{ }^{\dagger} P<0.01$ unpaired $t$-test.

There were no significant differences in lean mass between the groups over time (Fig. 5E and F). In line with the reduced fat mass, the weights of mesenteric and retroperitoneal WAT, and interscapular BAT depots were significantly smaller in the LVi- $\alpha$-MSH-EGFP-injected group compared with the LVi-EGFP group at termination (Table 1). There were no differences in the weights of liver, kidney or heart, or their weights relative to the body weight between the treatment groups (Table 1).

\section{Estimation of energy expenditure and BAT Ucp1 mRNA}

TEE $_{\text {bal }}$ did not differ between the treatment groups from day 21 to day 56 (LVi-EGFP: $11.8 \pm 0.2 \mathrm{kcal} / 24 \mathrm{~h}$ vs LVi- $\alpha$-MSH-EGFP: $12.1 \pm 0.4 \mathrm{kcal} / 24 \mathrm{~h}$ ). Despite lower BAT weight, the thermogenic capacity assessed as an Ucp1 mRNA level showed no difference between groups (Table 2).

\section{Glucose and lipid metabolism}

There was no significant difference in serum glucose levels after a $4 \mathrm{~h}$ fast or after glucose load in GTT analyzed over time (Fig. 6) or with the AUC (LVi-EGFP: $627 \pm 48$ vs LVi- $\alpha$-MSH-EGFP: $638 \pm 31 \mathrm{~min} \times \mathrm{mmol} / \mathrm{l})$. There were no differences in serum insulin, NEFAs, and cholesterol levels at the time of termination (Table 2).

\section{Urine and stool in metabolic cages}

The LVi- $\alpha$-MSH-EGFP-treated animals had lower 24-h urine volume compared with the LVi-EGFP-treated group (Table 2). The 24-h creatinine excretion did not differ, indicating that there was no difference in the renal function (Table 2). There were no significant differences in water and food intake or the weight of the stool (Table 2).

\section{Cardiovascular effects}

First, the sBP and the HR were measured by the tail-cuff method, which showed no significant differences in HR and sBP in the LVi- $\alpha$-MSH-EGFP group (701 $\pm 21 \mathrm{bpm}$ and $130 \pm 4 \mathrm{mmHg}$ ) compared with the LVi-EGFP group $(712 \pm 15 \mathrm{bpm}$ and $119 \pm 5 \mathrm{mmHg}, P=\mathrm{NS}$ and $P=0.149$ respectively). The hemodynamic analysis was continued using a less stressful and more accurate method, the radiotelemetry. Mice studied in telemetry represented the groups well in terms of the body weight and fat mass, which showed the significant treatment differences and no differences compared with the rest of mice in the corresponding group. By contrast, the difference between treatment groups in the 24-h urine volume was more dramatic in mice that underwent telemetry (LVi-EGFP: $1.21 \pm 0.29 \mathrm{ml}$ vs LVi- $\alpha$-MSH-EGFP: $0.28 \pm 0.05 \mathrm{ml}$ ) than the difference between the whole-group means (Table 2).

Baseline HR was consistently higher in the LVi- $\alpha$ MSH-EGFP group during the active darkness cycle, but no changes were noted in MAP (Fig. 7A and B). There were no differences in physical activity between the groups (Fig. 7C). To study autonomic control of cardiac function, acute cardiovascular responses to autonomic blocking agents were monitored. HR response to a control injection with saline was enhanced in the LVi- $\alpha$-MSH-EGFP group without a significant effect on MAP (Fig. 7D and G). This difference was abolished when mice were treated with metoprolol (Fig. 7E and $\mathrm{H}$ ), indicating an increased sympathetic activity in the LVi- $\alpha$-MSH-EGFP-treated mice. Furthermore, HR responses to muscarinic blockade with atropine were attenuated in the LVi- $\alpha$-MSH-EGFP group (Fig. 7I), indicating a lower cardiac vagal activity. Interestingly, the compensatory increase in $\mathrm{HR}$ as a response to vasodilatation induced by the $\alpha_{1}$-adrenergic receptor antagonist prazosin was enhanced in the LVi$\alpha$-MSH-EGFP group (Fig. 7I). These altered HR responses to autonomic blocking agents occurred without significant differences in MAP responses between the groups (Fig. 7F).

\section{Discussion}

In this study, we used a previously described and validated lentiviral gene delivery vector carrying a gene construct for production of $\alpha-\mathrm{MSH}$, a peptide fragment of

Published by Bioscientifica Ltd 

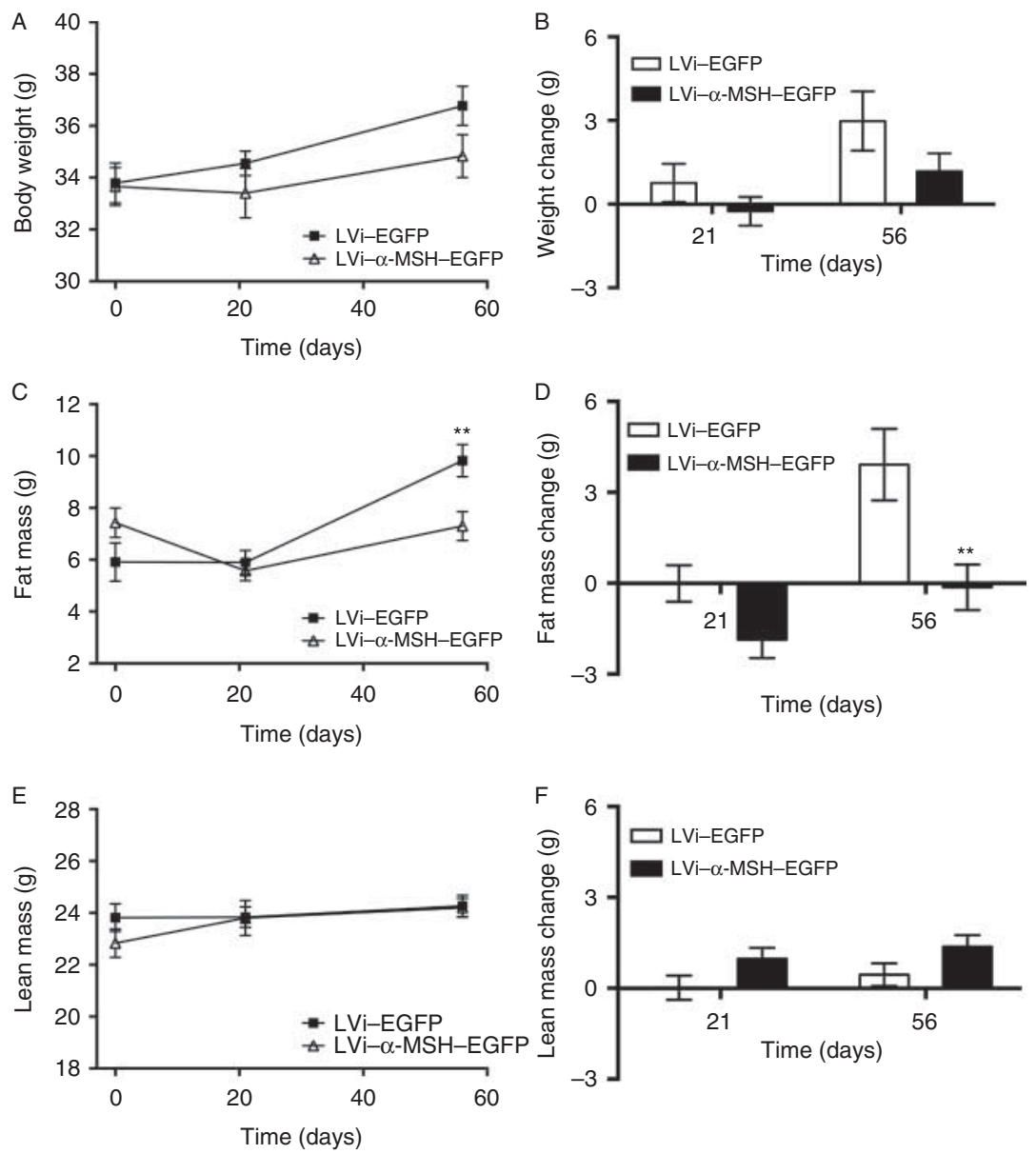

Figure 5

Effects on body composition on days 21 and 56 after the NTS injections of LVi- $\alpha$-MSH-EGFP $(n=9)$ and LVi-EGFP $(n=10)$. (A) Body weight, (B) change in body weight from day 0 , (C) fat mass, (D) change in fat mass from day 0 ,

prohormone POMC, and targeted the mouse NTS of the brain stem to determine the site-specific, metabolic, and hemodynamic effects of $\alpha$-MSH overexpression in mice feeding on a western-type diet. We hypothesized that the effects of acute $\alpha$-MSH administration into the NTS, i.e. inhibition of feeding and activation of energy expenditure, would lead to anti-obesity effects when $\alpha$-MSH was overexpressed in the long term. The results showed that body fat gain was indeed reduced. Furthermore, autonomic nervous system tone was shifted to activation of sympathetic tone and inhibition of parasympathetic tone as evidenced by regulation of HR.

The overexpression of $\alpha$-MSH was targeted to the medial NTS that endogenously expresses POMC using site-specific injections. Further targeting was provided by the promoter construct of the lentiviral vector that almost exclusively drives the expression in the neurons
(E) lean mass and $(F)$ change in lean mass from day $0 . * * P<0.01$; two-way ANOVA followed by the Bonferroni post-test.

(Jakobsson et al. 2003). No neuronal cell-type-specific targeting was used except that the $\alpha$-MSH translated from the transgene needs the endogenous POMC-processing enzymes. In order to verify the $\alpha$-MSH overexpression induced by the LVi- $\alpha$-MSH-EGFP vector, we used $\alpha$-MSH immunohistochemistry. Assessment of coronal sections from the LVi-EGFP control mice revealed a staining pattern similar to what has been reported in the rat, i.e. a low overall level of $\alpha$-MSH immunoreactivity that is most abundant in the commissural area and less evident in the dorsal and medial subdivisions of NTS (Zheng et al. 2010). The medial NTS harbors a POMC-neuron population that was identified in the POMC-GFP mouse and is responsive to peripheral signals (Cowley et al. 2001, Fan et al. 2004). The LVi- $\alpha$-MSH-EGFP-induced overexpression was evident in the target site of the injections (dorsolateral to medial NTS at interaural structure of $-3.5 \mathrm{~mm}$ ).

Published by Bioscientifica Ltd. 
Table 2 Metabolic cage analysis over $24 \mathrm{~h}$ at day 50 and serum and tissue markers at termination in LVi-EGFP-treated mice $(n=8-10)$ and LVi- $\alpha-\mathrm{MSH}-\mathrm{EGFP}$-treated mice $(n=7-9)$

Food intake $(\mathrm{g} / 24 \mathrm{~h})$
Stool $(\mathrm{g} / 24 \mathrm{~h})$
Water intake $(\mathrm{g} / 24 \mathrm{~h})$
Urine $(\mathrm{ml} / 24 \mathrm{~h})$
Creatinine $(\mu \mathrm{g} / 24 \mathrm{~h})$
NEFAs $(\mathrm{mmol} / \mathrm{l})$
Cholesterol $(\mathrm{mg} / \mathrm{ml})$
Insulin $(\mu \mathrm{g} / \mathrm{l})$
BAT UCP1 mRNA

\begin{tabular}{|c|c|}
\hline LVi-EGFP & LVi- $\alpha-M S H-E G F P$ \\
\hline $3.9 \pm 0.3$ & $3.7 \pm 0.3$ \\
\hline $0.36 \pm 0.03$ & $0.30 \pm 0.04$ \\
\hline $3.0 \pm 0.4$ & $2.4 \pm 0.4$ \\
\hline $0.97 \pm 0.14$ & $0.47 \pm 0.11$ * \\
\hline $391 \pm 36$ & $388 \pm 148$ \\
\hline $0.37 \pm 0.03$ & $0.35 \pm 0.04$ \\
\hline $2.63 \pm 0.17$ & $2.97 \pm 0.29$ \\
\hline $0.77 \pm 0.22$ & $1.02 \pm 0.24$ \\
\hline $1.06 \pm 0.13$ & $1.01 \pm 0.16$ \\
\hline
\end{tabular}

NEFAs, non-esterified fatty acids; BAT, brown adipose tissue; UCP1, uncoupling protein $1 .{ }^{*} P<0.05 \mathrm{LVi}-\alpha-\mathrm{MSH}-\mathrm{EGFP}$ compared with $\mathrm{LVi}-$ EGFP; unpaired $t$-test.

Semiquantification yielded a moderate, but statistically significant 1.65 -fold increase in the NTS area at the rostrocaudal level of the injection.

The most prominent effect of LVi- $\alpha$-MSH-EGFP treatment in the NTS was the reduction in fat mass gain that eventually led to significantly lower body and fat depot weights in mice fed on a moderately obesogenic medium-fat $(25 \mathrm{kcal} \%)$ western diet. The difference was significant when comparing with the control group and with mice that received LVi- $\alpha$-MSH-EGFP injections that did not hit the NTS, supporting that the effects of $\alpha$-MSH were indeed mediated in the NTS. The reduction in fat mass gain by chronic melanocortin activation is a constant finding in obese rodents. In our previous study, we targeted the ARC of the hypothalamus using the same gene delivery system overexpressing $\alpha$-MSH and showed a decrease in adiposity in mice feeding on a high-fat diet (Eerola et al. 2013). Furthermore, gene modifications such as MSH (POMC) overexpression in Tg-MSH mice (Lee et al. $2007)$ or deficiency of $\alpha$-MSH-degrading enzyme PRCP (Jeong et al. 2012a,b) and NTS-targeted overexpression of $P O M C$ by adeno-associated virus (AAV) delivery (Zhang et al. 2010) have all showed reduced adiposity.

The mechanisms leading to reduced adiposity by central melanocortin activation include a small decrease in feeding, increased $\mathrm{TEE}_{\mathrm{bal}}$, increased physical activity, and BAT thermogenesis (Lee et al. 2007, Semjonous et al. 2009, Wallingford et al. 2009, Jeong et al. 2012a,b). NTSspecific administration was shown to acutely decrease feeding and increase core temperature and spontaneous physical activity in rats (Skibicka \& Grill 2009), whereas chronic overexpression of POMC decreased feeding and increased physical activity, but did not change BAT thermogenesis in DIO rats with established obesity
(Zhang et al. 2010). In this study, there was only a transient reduction in food intake in the $\mathrm{LVi}-\alpha-\mathrm{MSH}-$ EGFP-treated group and no difference in estimated $\mathrm{TEE}_{\text {bal }}$ or home cage physical activity. Sympathetic activation plays an important role in mediating the weight-reducing effects of MC4R signaling (Rossi et al. 2011). Thus, an increased sympathetic activity was likely to contribute to lower fat mass gain in LVi- $\alpha$-MSH-EGFP-treated mice. However, this was not mediated by increased BAT thermogenesis, which fits with the effects of NTS-specific overexpression of POMC in rats (Zhang et al. 2010). Instead, activation of sympathetic innervation to WAT could play a role as it has previously been shown to mediate the stimulatory effects of central melanocortin activation on lipid mobilization and oxidation in WAT (Nogueiras et al. 2007). In fact, WAT has $\sim 30-50 \%$ of the total oxidative capacity and has been shown to increase energy expenditure in response to high-energy diets independent of BAT (Kopecky et al. 1996, Vosselman et al. 2012).

The LVi- $\alpha$-MSH-EGFP treatment did not have a significant impact on glucose tolerance or serum insulin level. This is contrary to what has been observed in other genetic melanocortin activation models: the universally overexpressing Tg-MSH mice (Lee et al. 2007) and PRCPdeficient mice (Jeong et al. 2012b) and the site-specifically overexpressing mice treated with LVi- $\alpha$-MSH-EGFP in the ARC (Eerola et al. 2013) or POMC-AAV in the NTS (Zhang et al. 2010). In these previous studies, improved glucose

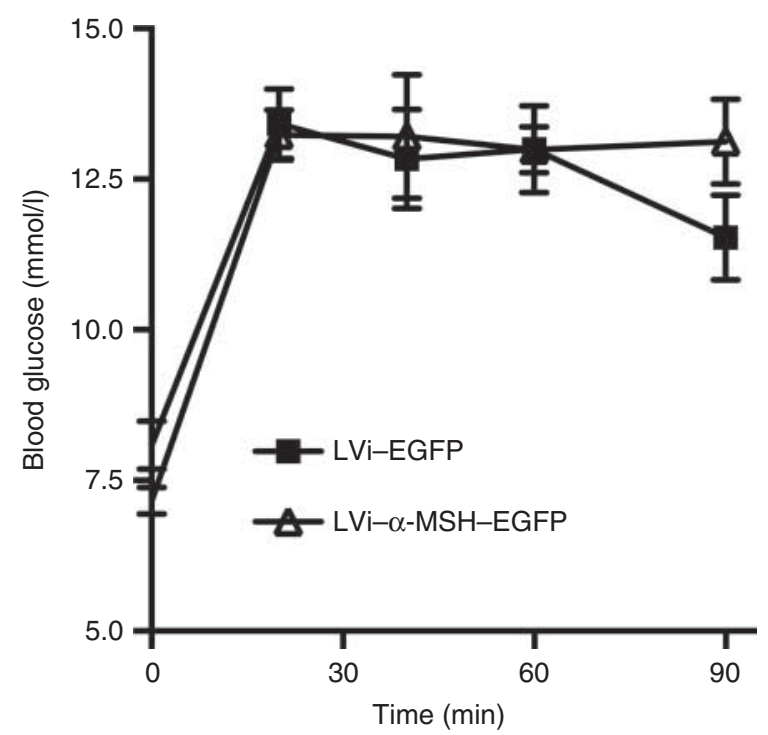

Figure 6

Glucose tolerance test (GTT) in LVi- $\alpha$-MSH-EGFP-treated mice $(n=8)$ and LVi-EGFP-treated mice $(n=10)$ on day 26 after the injections.

Published by Bioscientifica Ltd. 

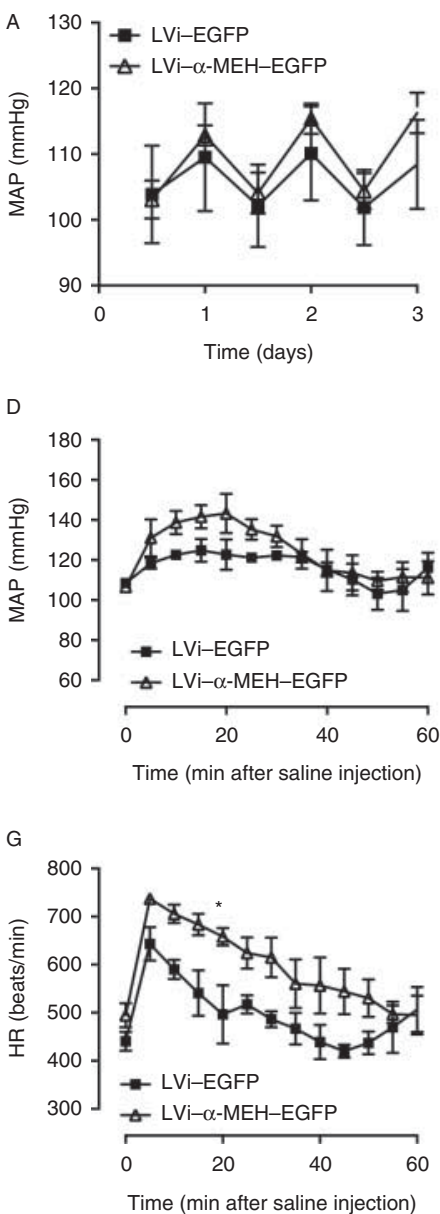
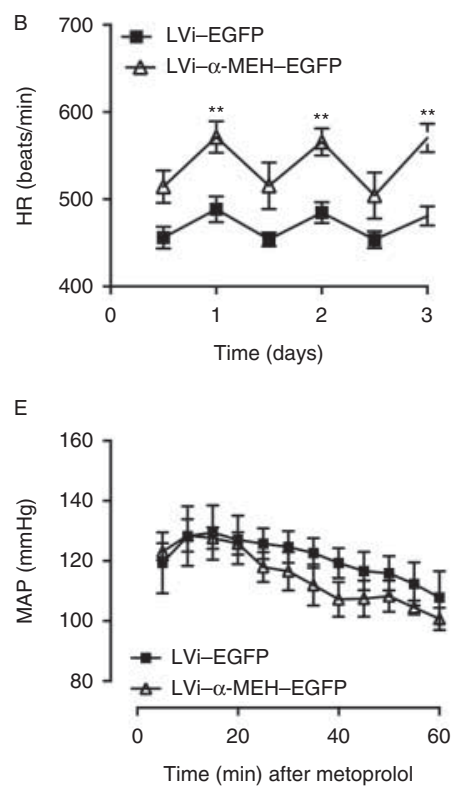

$\mathrm{H}$

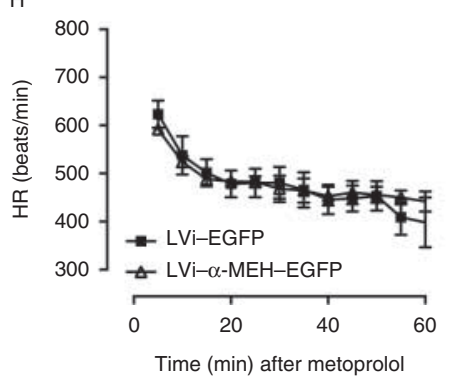

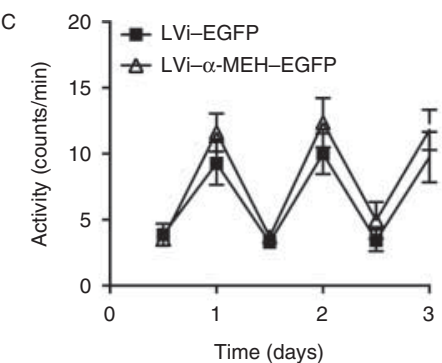
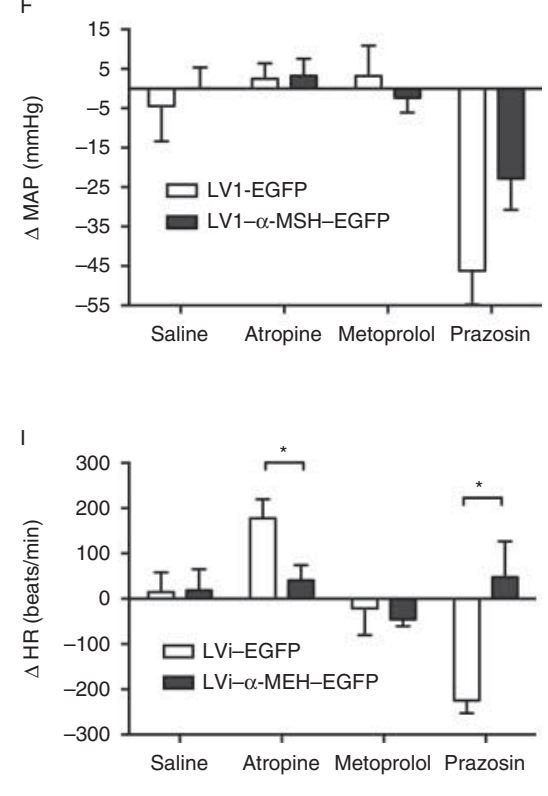

Figure 7

Telemetric cardiovascular measurements of LVi-EGFP-treated mice $(n=4)$ and LVi- $\alpha$-MSH-EGFP-treated mice $(n=4)$. (A) Mean arterial pressure (MAP), (B) heart rate (HR) and (C) physical activity showing mean values for $12 \mathrm{~h}$ light: $12 \mathrm{~h}$ darkness periods over 3 day baseline measurements. Effects of saline injection on (D) MAP and (G) HR. Effects of metoprolol injection

tolerance accompanied reduced adiposity and was more evident in obesity, and moderate level of obesity and lack of significant difference in fat mass at the time of GTT could explain the current finding. However, $\alpha$-MSH has also been demonstrated to regulate insulin levels and glucose homeostasis independent of the changes in body weight via regulation of the autonomic nervous system (Obici et al. 2001, Rossi et al. 2011, Sohn et al. 2013). Recent research using cell-specific genetic manipulation of $\mathrm{Mc} 4 \mathrm{r}$ has demonstrated the key role of MC4R in the cholinergic neurons in inhibition of parasympathetic neurons and activation of sympathetic neurons leading to changes in energy, glucose, and cardiovascular homeostasis (Rossi et al. 2011, Sohn et al. 2013). Although the analysis of HR control by the autonomic nervous system on (E) MAP and (H) HR. *P<0.05, ** $<0.05$; two-way ANOVA followed by the Bonferroni post-test. Change from baseline in (F) MAP and (I) HR 45-60 min after the administration of saline or autonomic nervous system-blocking agents atropine, metoprolol, or prazosin. ${ }^{*} P<0.05$; Mann-Whitney $U$ test.

showed an increased sympathetic tone and a decreased parasympathetic tone, it was not reflected to the longterm changes in insulin and glucose levels in this study.

The analysis of hemodynamics showed that the LVi$\alpha$-MSH-EGFP treatment increased the HR and did not change blood pressure. Stress induced by saline injection increased the HR more in the LVi- $\alpha$-MSH-EGFP-treated mice, which was abolished by a $\beta$-adrenoceptor blockade pointing to an increased sympathetic activity. Furthermore, a blockade of parasympathetic activity by atropine elevated the HR to a less extent in the LVi- $\alpha$-MSH-EGFPtreated mice pointing to a decreased vagal tone in the cardiac control. In line with our observations, acute administration of a $\alpha-\mathrm{MSH}$ analog at a low dose into the NTS was shown to increase the HR in conscious rats

Published by Bioscientifica Ltd. 
(Skibicka \& Grill 2009). Their setting could resemble our setting (low dosing vs genetic overexpression and use of conscious animals) better than other studies showing bradycardic and depressor effects after NTS administration of $\alpha$-MSH in anesthetized rodents (Li et al. 1996, Pavia et al. 2003, Tai et al. 2007). An increased overall SNS activity was evident in rats after the POMC-AAV administration into the NTS, which also fits with our finding (Zhang et al. 2010). The inhibition of vagal activity via MC4R has been recently studied ex vivo using electrophysiology and reported to take place in the dorsal motor nucleus of the vagus (DMV) nerve, which receives POMC projections from the NTS (Sohn et al. 2013). Our results show that the inhibition of vagal activity is evident in vivo and is sustained when $\alpha-\mathrm{MSH}$ is overexpressed in the NTS neurons.

Furthermore, the LVi- $\alpha$-MSH-EGFP mice showed an enhanced HR response to prazosin-induced vasodilatation. This finding suggests an improved baroreceptor reflex induced by chronic melanocortin activation in the NTS, which is an important site integrating the baroreceptor signals (Guyenet 2006). It is supported by our earlier studies showing improved baroreceptor function in the Tg-MSH mice and in mice after chronic treatment with a peripherally administered melanocortin analog (Rinne et al. 2008), and gives a potential site of action for melanocortin regulation of the baroreflex.

The LVi- $\alpha$-MSH-EGFP treatment decreased 24-h urine volume compared with the LVi-EGFP treatment. This is contrary to the known diuretic action of $\alpha$-MSH analogs, which, however, seems to be mediated by peripheral MC3R (Chen et al. 1997, Ni et al. 1998). Our finding instead may fit with the studies showing that central melanocortin activation increases the renal sympathetic activity (Haynes et al. 1999) and modulates renal function via sympathetic pathways (Kuo et al. 2004). Urine collection in metabolic cages disposes mice to the stress of novel environment and wire bottom leading to activation of the SNS. As an increased sympathetic activity can decrease diuresis, the result may reflect enhanced activation of the renal sympathetic activity in $\mathrm{LVi}-\alpha-\mathrm{MSH}-$ EGFP-treated mice. This suggests that $\alpha$-MSH overexpression in the NTS also increases, in addition to cardiac, renal sympathetic activity.

In conclusion, we have shown that lentiviral delivery of the $\alpha$-Msh gene construct based on the endogenous POMC prohormone N-terminal sequence to the NTS decreases adiposity in mildly obese mice. The significant change in body composition over time was not explained by changes in food intake, physical activity, or BAT thermogenesis. Activation of SNS and inhibition of parasympathetic nervous system increased the HR, and sympathetic activation to WAT most probably contributed to the adiposity effect. The results underline the key role of NTS in the $\alpha$-MSH-induced long-term anti-obesity effect and in the regulation of the autonomic nervous system.

\section{Supplementary data}

This is linked to the online version of the paper at http://dx.doi.org/10.1530/ JOE-14-0064.

\section{Declaration of interest}

The authors declare that there is no conflict of interest that could be perceived as prejudicing the impartiality of the research reported.

\section{Funding}

This work was supported by grants from the Academy of Finland, the Finnish Cultural Foundation, the Varsinais-Suomi Regional Fund, and the FinPharma Doctoral Program.

\section{Acknowledgements}

The authors would like to acknowledge the excellent work of Erica Nyman in preparing tissues and Sanna Bastman in telemetry surgery, Satu Mäkelä for the support in operations, and Wendy Nordlund and Raija Kaartosalmi in biochemical assays.

\section{References}

Appleyard SM, Hayward M, Young JI, Butler AA, Cone RD, Rubinstein M \& Low MJ 2003 A role for the endogenous opioid $\beta$-endorphin in energy homeostasis. Endocrinology 144 1753-1760. (doi:10.1210/en.2002221096)

Berthoud HR \& Morrison C 2008 The brain, appetite, and obesity. Annual Review of Psychology 59 55-92. (doi:10.1146/annurev.psych.59.103006. 093551)

Biebermann H, Kuhnen P, Kleinau G \& Krude H 2012 The neuroendocrine circuitry controlled by POMC, MSH, and AGRP. Handbook of Experimental Pharmacology 209 47-75. (doi:10.1007/978-3-64224716-3_3)

Chen XW, Ying WZ, Valentin JP, Ling KT, Lin SY, Wiedemann E \& Humphreys MH 1997 Mechanism of the natriuretic action of $\gamma$-melanocyte-stimulating hormone. American Journal of Physiology 272 R1946-R1953.

Cowley MA, Pronchuk N, Fan W, Dinulescu DM, Colmers WF \& Cone RD 1999 Integration of NPY, AGRP, and melanocortin signals in the hypothalamic paraventricular nucleus: evidence of a cellular basis for the adipostat. Neuron 24 155-163. (doi:10.1016/S0896-6273(00) 80829-6)

Cowley MA, Smart JL, Rubinstein M, Cerdan MG, Diano S, Horvath TL, Cone RD \& Low MJ 2001 Leptin activates anorexigenic POMC neurons through a neural network in the arcuate nucleus. Nature $\mathbf{4 1 1} 480-484$. (doi:10.1038/35078085)

Diano S 2011 New aspects of melanocortin signaling: a role for PRCP in $\alpha$-MSH degradation. Frontiers in Neuroendocrinology 32 70-83. (doi:10.1016/j.yfrne.2010.09.001) http://joe.endocrinology-journals.org DOI: 10.1530/JOE-14-0064
C 2014 Society for Endocrinology Printed in Great Britain
Published by Bioscientifica Ltd. 
Eerola K, Nordlund W, Virtanen S, Dickens AM, Mattila M, Ruohonen ST, Chua SC, Wardlaw SL, Savontaus M \& Savontaus E 2013 Lentivirus mediated $\alpha$-melanocyte stimulating hormone overexpression in the hypothalamus decreases diet induced obesity in mice. Journal of Neuroendocrinology 25 1298-1307. (doi:10.1111/jne.12109)

Eichhorn P, Schwandt P \& Richter WO 1995 Proopiomelanocorticotropin (POMC), peptides and lipoprotein lipase activity in vitro. Peptides 16 665-671. (doi:10.1016/0196-9781(95)00026-G)

Elmquist JK, Elias CF \& Saper CB 1999 From lesions to leptin: hypothalamic control of food intake and body weight. Neuron 22 221-232. (doi:10.1016/S0896-6273(00)81084-3)

Fan W, Boston BA, Kesterson RA, Hruby VJ \& Cone RD 1997 Role of melanocortinergic neurons in feeding and the agouti obesity syndrome. Nature 385 165-168. (doi:10.1038/385165a0)

Fan W, Ellacott KL, Halatchev IG, Takahashi K, Yu P \& Cone RD 2004 Cholecystokinin-mediated suppression of feeding involves the brainstem melanocortin system. Nature Neuroscience 7 335-336. (doi:10.1038/nn1214)

Farooqi IS, Yeo GS, Keogh JM, Aminian S, Jebb SA, Butler G, Cheetham T \& O'Rahilly S 2000 Dominant and recessive inheritance of morbid obesity associated with melanocortin 4 receptor deficiency. Journal of Clinical Investigation 106 271-279. (doi:10.1172/JCI9397)

Franklin KBJ \& Paxinos G 1997 In The Mouse Brain in Stereotaxic Coordinates, 1st edn. San Diego, CA, USA: Academic Press.

Grill HJ, Ginsberg AB, Seeley RJ \& Kaplan JM 1998 Brainstem application of melanocortin receptor ligands produces long-lasting effects on feeding and body weight. Journal of Neuroscience $\mathbf{1 8} 10128-10135$.

Guyenet PG 2006 The sympathetic control of blood pressure. Nature Reviews. Neuroscience 7 335-346. (doi:10.1038/nrn1902)

Haynes WG, Morgan DA, Djalali A, Sivitz WI \& Mark AL 1999 Interactions between the melanocortin system and leptin in control of sympathetic nerve traffic. Hypertension 33 542-547. (doi:10.1161/01.HYP.33.1.542)

Hinney A, Bettecken T, Tarnow P, Brumm H, Reichwald K, Lichtner P, Scherag A, Nguyen TT, Schlumberger P, Rief W et al. 2006 Prevalence, spectrum, and functional characterization of melanocortin-4 receptor gene mutations in a representative population-based sample and obese adults from Germany. Journal of Clinical Endocrinology and Metabolism 91 1761-1769. (doi:10.1210/jc.2005-2056)

Jakobsson J, Ericson C, Jansson M, Bjork E \& Lundberg C 2003 Targeted transgene expression in rat brain using lentiviral vectors. Journal of Neuroscience Research 73 876-885. (doi:10.1002/jnr.10719)

Jeong JK, Szabo G, Kelly K \& Diano S 2012a Prolyl carboxypeptidase regulates energy expenditure and the thyroid axis. Endocrinology 153 683-689. (doi:10.1210/en.2011-1399)

Jeong JK, Szabo G, Raso GM, Meli R \& Diano S 2012b Deletion of prolyl carboxypeptidase attenuates the metabolic effects of diet-induced obesity. American Journal of Physiology. Endocrinology and Metabolism 302 E1502-E1510. (doi:10.1152/ajpendo.00544.2011)

Kopecky J, Rossmeisl M, Hodny Z, Syrovy I, Horakova M \& Kolarova P 1996 Reduction of dietary obesity in aP2-ucp transgenic mice: mechanism and adipose tissue morphology. American Journal of Physiology $\mathbf{2 7 0}$ E776-E786.

Kuo JJ, da Silva AA, Tallam LS \& Hall JE 2004 Role of adrenergic activity in pressor responses to chronic melanocortin receptor activation. Hypertension 43 370-375. (doi:10.1161/01.HYP.0000111836.54204.93)

Lee M, Kim A, Chua SC Jr, Obici S \& Wardlaw SL 2007 Transgenic MSH overexpression attenuates the metabolic effects of a high-fat diet. American Journal of Physiology. Endocrinology and Metabolism 293 E121-E131. (doi:10.1152/ajpendo.00555.2006)

Lee M, Kim A, Conwell IM, Hruby V, Mayorov A, Cai M \& Wardlaw SL 2008 Effects of selective modulation of the central melanocortin-3-receptor on food intake and hypothalamic POMC expression. Peptides 29 440-447. (doi:10.1016/j.peptides.2007.11.005)

Li SJ, Varga K, Archer P, Hruby VJ, Sharma SD, Kesterson RA, Cone RD \& Kunos G 1996 Melanocortin antagonists define two distinct pathways of cardiovascular control by $\alpha$ - and $\gamma$-melanocyte-stimulating hormones. Journal of Neuroscience 16 5182-5188.

Li G, Mobbs CV \& Scarpace PJ 2003 Central pro-opiomelanocortin gene delivery results in hypophagia, reduced visceral adiposity, and improved insulin sensitivity in genetically obese Zucker rats. Diabetes 52 1951-1957. (doi:10.2337/diabetes.52.8.1951)

Li G, Zhang Y, Wilsey JT \& Scarpace PJ 2005 Hypothalamic proopiomelanocortin gene delivery ameliorates obesity and glucose intolerance in aged rats. Diabetologia 48 2376-2385. (doi:10.1007/ s00125-005-1943-8)

Li G, Zhang Y, Cheng KY \& Scarpace PJ 2007 Lean rats with hypothalamic pro-opiomelanocortin overexpression exhibit greater diet-induced obesity and impaired central melanocortin responsiveness. Diabetologia 50 1490-1499. (doi:10.1007/s00125-007-0685-1)

Low MJ, Hayward MD, Appleyard SM \& Rubinstein M 2003 Statedependent modulation of feeding behavior by proopiomelanocortinderived $\beta$-endorphin. Annals of the New York Academy of Sciences 994 192-201. (doi:10.1111/j.1749-6632.2003.tb03180.x)

Lu D, Willard D, Patel IR, Kadwell S, Overton L, Kost T, Luther M, Chen W, Woychik RP \& Wilkison WO 1994 Agouti protein is an antagonist of the melanocyte-stimulating-hormone receptor. Nature 371 799-802. (doi:10.1038/371799a0)

McMinn JE, Wilkinson CW, Havel PJ, Woods SC \& Schwartz MW 2000 Effect of intracerebroventricular $\alpha$-MSH on food intake, adiposity, c-fos induction, and neuropeptide expression. American Journal of Physiology. Regulatory, Integrative and Comparative Physiology 279 R695-R703.

Miller R, Aaron W, Toneff T, Vishnuvardhan D, Beinfeld MC \& Hook VY 2003 Obliteration of $\alpha$-melanocyte-stimulating hormone derived from POMC in pituitary and brains of PC2-deficient mice. Journal of Neurochemistry 86 556-563. (doi:10.1046/j.1471-4159.2003.01856.x)

Ni XP, Kesterson RA, Sharma SD, Hruby VJ, Cone RD, Wiedemann E \& Humphreys MH 1998 Prevention of reflex natriuresis after acute unilateral nephrectomy by melanocortin receptor antagonists. American Journal of Physiology 274 R931-R938.

Nogueiras R, Wiedmer P, Perez-Tilve D, Veyrat-Durebex C, Keogh JM, Sutton GM, Pfluger PT, Castaneda TR, Neschen S, Hofmann SM et al. 2007 The central melanocortin system directly controls peripheral lipid metabolism. Journal of Clinical Investigation 117 3475-3488. (doi:10.1172/JCI31743)

Obici S, Feng Z, Tan J, Liu L, Karkanias G \& Rossetti L 2001 Central melanocortin receptors regulate insulin action. Journal of Clinical Investigation 108 1079-1085. (doi:10.1172/JCI200112954)

Pavia JM, Schioth HB \& Morris MJ 2003 Role of MC4 receptors in the depressor and bradycardic effects of $\alpha$-MSH in the nucleus tractus solitarii of the rat. Neuroreport 14 703-707. (doi:10.1097/00001756200304150-00009)

Petervari E, Szabad AO, Soos S, Garami A, Szekely M \& Balasko M 2011 Central $\alpha$-MSH infusion in rats: disparate anorexic vs. metabolic changes with aging. Regulatory Peptides 166 105-111. (doi:10.1016/ j.regpep.2010.10.002)

Rasband WS 1997-2012 ImageJ (http://Imagej.nih.gov/ij/). In Bethesda, Maryland, USA: National Institute of Health.

Ravussin Y, Gutman R, LeDuc CA \& Leibel RL 2013 Estimating energy expenditure in mice using an energy balance technique. International Journal of Obesity 37 399-403. (doi:10.1038/ijo.2012.105)

Richter WO, Jacob BG \& Schwandt P 1990 Processing of the lipidmobilizing peptide $\beta$-lipotropin in rabbit adipose tissue. Molecular and Cellular Endocrinology 71 229-238. (doi:10.1016/0303-7207(90) 90028-7)

Rinne P, Harjunpaa J, Scheinin M \& Savontaus E 2008 Blood pressure regulation and cardiac autonomic control in mice overexpressing $\alpha$ - and $\gamma$-melanocyte stimulating hormone. Peptides 29 1943-1952. (doi:10.1016/j.peptides.2008.06.012)

Rinne P, Harjunpaa J, Makela S \& Savontaus E 2013 Genetic and pharmacological mouse models of chronic melanocortin activation 
show enhanced baroreflex control of heart rate. Regulatory Peptides 182 19-27. (doi:10.1016/j.regpep.2012.12.002)

Rossi J, Balthasar N, Olson D, Scott M, Berglund E, Lee CE, Choi MJ, Lauzon D, Lowell BB \& Elmquist JK 2011 Melanocortin-4 receptors expressed by cholinergic neurons regulate energy balance and glucose homeostasis. Cell Metabolism 13 195-204. (doi:10.1016/j.cmet. 2011.01.010)

Ruifrok AC, Katz RL \& Johnston DA 2003 Comparison of quantification of histochemical staining by hue-saturation-intensity (HSI) transformation and color-deconvolution. Applied Immunohistochemistry \& Molecular Morphology 11 85-91.

Savontaus E, Breen TL, Kim A, Yang LM, Chua SC Jr \& Wardlaw SL 2004 Metabolic effects of transgenic melanocyte-stimulating hormone overexpression in lean and obese mice. Endocrinology 145 3881-3891. (doi:10.1210/en.2004-0263)

Seidah NG, Fournier H, Boileau G, Benjannet S, Rondeau N \& Chretien M 1992 The cDNA structure of the porcine pro-hormone convertase PC2 and the comparative processing by PC1 and PC2 of the N-terminal glycopeptide segment of porcine POMC. FEBS Letters 310 235-239. (doi:10.1016/0014-5793(92)81339-N)

Semjonous NM, Smith KL, Parkinson JR, Gunner DJ, Liu YL, Murphy KG, Ghatei MA, Bloom SR \& Small CJ 2009 Coordinated changes in energy intake and expenditure following hypothalamic administration of neuropeptides involved in energy balance. International Journal of Obesity 33 775-785. (doi:10.1038/ijo.2009.96)

Skibicka KP \& Grill HJ 2009 Hypothalamic and hindbrain melanocortin receptors contribute to the feeding, thermogenic, and cardiovascular action of melanocortins. Endocrinology 150 5351-5361. (doi:10.1210/ en.2009-0804)

Sohn JW, Harris LE, Berglund ED, Liu T, Vong L, Lowell BB, Balthasar N, Williams KW \& Elmquist JK 2013 Melanocortin 4 receptors reciprocally regulate sympathetic and parasympathetic preganglionic neurons. Cell 152 612-619. (doi:10.1016/j.cell.2012.12.022)

Sutton GM, Duos B, Patterson LM \& Berthoud HR 2005 Melanocortinergic modulation of cholecystokinin-induced suppression of feeding through extracellular signal-regulated kinase signaling in rat solitary nucleus. Endocrinology 146 3739-3747. (doi:10.1210/ en.2005-0562)

Tai MH, Weng WT, Lo WC, Chan JY, Lin CJ, Lam HC \& Tseng CJ 2007 Role of nitric oxide in $\alpha$-melanocyte-stimulating hormone-induced hypotension in the nucleus tractus solitarii of the spontaneously hypertensive rats. Journal of Pharmacology and Experimental Therapeutics 321 455-461. (doi:10.1124/jpet.106.118299)

Tung YC, Piper SJ, Yeung D, O’Rahilly S \& Coll AP 2006 A comparative study of the central effects of specific proopiomelancortin (POMC)derived melanocortin peptides on food intake and body weight in POMC null mice. Endocrinology 147 5940-5947. (doi:10.1210/en. 2006-0866)

Vaisse C, Clement K, Durand E, Hercberg S, Guy-Grand B \& Froguel P 2000 Melanocortin-4 receptor mutations are a frequent and heterogeneous cause of morbid obesity. Journal of Clinical Investigation 106 253-262. (doi:10.1172/JCI9238)

Vosselman MJ, van der Lans AA, Brans B, Wierts R, van Baak MA, Schrauwen P \& van Marken Lichtenbelt WD 2012 Systemic $\beta$ adrenergic stimulation of thermogenesis is not accompanied by brown adipose tissue activity in humans. Diabetes $613106-3113$. (doi:10.2337/db12-0288)

Wallingford N, Perroud B, Gao Q, Coppola A, Gyengesi E, Liu ZW, Gao XB, Diament A, Haus KA, Shariat-Madar Z et al. 2009 Prolylcarboxypeptidase regulates food intake by inactivating $\alpha$-MSH in rodents. Journal of Clinical Investigation 119 2291-2303. (doi:10.1172/JCI37209)

Zanutto BS, Valentinuzzi ME \& Segura ET 2010 Neural set point for the control of arterial pressure: role of the nucleus tractus solitarius. Biomedical Engineering Online 9 4. (doi:10.1186/1475-925X-9-4)

Zhang Y, Rodrigues E, Gao YX, King M, Cheng KY, Erdos B, Tumer N, Carter C \& Scarpace PJ 2010 Pro-opiomelanocortin gene transfer to the nucleus of the solitary track but not arcuate nucleus ameliorates chronic diet-induced obesity. Neuroscience 169 1662-1671. (doi:10.1016/j.neuroscience.2010.06.001)

Zheng H, Patterson LM, Phifer CB \& Berthoud HR 2005 Brain stem melanocortinergic modulation of meal size and identification of hypothalamic POMC projections. American Journal of Physiology. Regulatory, Integrative and Comparative Physiology 289 R247-R258. (doi:10.1152/ajpregu.00869.2004)

Zheng H, Patterson LM, Rhodes CJ, Louis GW, Skibicka KP, Grill HJ, Myers MG Jr \& Berthoud HR 2010 A potential role for hypothalamomedullary POMC projections in leptin-induced suppression of food intake. American Journal of Physiology. Regulatory, Integrative and Comparative Physiology 298 R720-R728. (doi:10.1152/ajpregu. 00619.2009)

Received in final form 7 May 2014

Accepted 12 May 2014

Accepted Preprint published online 14 May 2014 http://joe.endocrinology-journals.org DOI: 10.1530/JOE-14-0064
C 2014 Society for Endocrinology Printed in Great Britain
Published by Bioscientifica Ltd. 